Article Type: Research Paper

\title{
Taxing Celebrity Social Media Endorsements Income: A Preliminary Study of Instagram Celebrities
}

Afrizal $\operatorname{Tahar}^{1 *}$, Listya Maharani Rizkia ${ }^{2}$, and Eko Hariyanto ${ }^{3}$

\begin{abstract}
:
Research aims: This study investigates how taxation should be applied to the income of Instagram celebrities ('celebgrams') obtained from endorsement activities on social media. In detail, this study aims to find out how income from endorsement could be categorized as taxable income, as well as investigating how a possible collection strategy could be executed. In addition, this study explores the perceptions of celebgrams regarding the taxation of their endorsement income.
\end{abstract}

${ }_{1,2}^{2}$ Department of Accounting, Faculty of Economics and Business, Universitas Muhammadiyah Yogyakarta, Special Region of Yogyakarta, Indonesia.

${ }^{3}$ Department of Accounting, Universitas Muhammadiyah Purwokerto, Purwokerto, Indonesia

\section{*CORRESPONDENCE:}

afrizal@umy.ac.id

THIS ARTICLE IS AVAILABLE IN:

http://journal.umy.ac.id/index.php/ai

DOI: 10.18196/jai.2103167

\section{CITATION:}

Tahar, A., Rizkia, L. M., \& Hariyanto, E. (2020). Taxing

Celebrity Social Media

Endorsements Income: A

Preliminary Study of Instagram

Celebrities. Journal of Accounting and Investment, 21(3), 602-621.

\section{ARTICLE HISTORY}

\section{Received:}

08 July 2020

Reviewed:

14 July 2020

05 Aug 2020

Revised:

24 July 2020

10 Aug 2020

Accepted:

05 Sep 2020

Design/Methodology/Approach: Semi-structured interviews were employed to obtain the data from an informant samples made up of a tax official, a tax consultant, a tax academic, an information technology expert, and several celebgrams.

Research findings: The results of this study reveal that celebgram income from endorsement can be taxable in the categories of both income tax and valueadded tax. In addition, endorsement tax needs a special unit dedicated to its collection supported by capable employees and adequate information technology. Moreover, the majority of the celebgrams agree that if their income from endorsement is to be taxed, this should be based on fair and clear treatment.

Theoretical contribution/ Originality: This research is a pioneering study related to the topic of tax on social-media endorsement income.

Practitioner/Policy implication: This study result can be used as inputs for regulators to optimize tax revenue from Indonesia's large e-commerce sector, and especially from endorsement activities.

Research limitation/Implication: This research was conducted in Yogyakarta using a qualitative approach. Therefore, generalizations from the results of this research cannot be made.

Keywords: Celebrity; Endorsement; Income; Instagram; Tax

\section{Introduction}

The rapid development of information technology in era 4.0 has shifted the paradigm around society's search for income. The emergence of various social-media platforms has not only served to connect people, but has also created a new market place (Cahyono, 2016; Rahman \& Panuju, 2017). Social media itself provides an online space in which people can exchange information and interact. The term 'social media' refers in particular to new media, such as those internet-enabled social-networking 
Tahar, Rizkia, \& Hariyanto

Taxing Celebrity Social Media Endorsements Income: ...

sites such as Facebook, Twitter, YouTube, Instagram, Blogspot and many others (Utami, Lestari, \& Putri, 2016)

Today, it can be seen that several social-media platforms such as Facebook, Instagram and Twitter have become the main initiator marketplaces for e-commerce in many developing countries, including Indonesia. Many companies use social media because they recognize the need to engage in existing social-media conversations to protect their company or brand reputation, to increase customer engagement, and/or to increase online sales (Keegan \& Rowley, 2017). Social media offers active interaction between businesses and customers. In addition, social media can also broaden the scope and reach of marketing (Virtanen, Björk, \& Sjöström, 2017). Instagram is an example of a social-media format that companies use in establishing interactive communications with their customers. Instagram entered the online world in 2010 as a free mobile application allowing users to edit and share images and videos from their mobile devices (Virtanen et al., 2017).

Today, internet users tend to be more interested in visual language than text. This makes Instagram a very effective promotional medium. Instagram maximizes its features through pictures and videos to a greater extent than other social-media sites. This allows users to see the desired product easily, and that is where business people see opportunities (Febiyan, 2015). The number of Instagram users is increasing. In 2016, worldwide users reached 600 million, 22 million (3.67\%) of these in Indonesia. By 2018, Instagram users in Indonesia reached 59 million, making it the fourth-largest user in the world after the United States (121 million), India (71 million), and Brazil (64 million) (OkeFinance, 2019), implying that the country offers great opportunities to market products or services through Instagram (Yusup, Rais, \& Sari, 2018).

Given the level of growth in Instagram users detailed above, promotional strategy on social media such as Instagram has today become an important new trend. One strategy employed by companies is to hire out endorsement services to individuals posting creative content who have many followers and significant influence on social media. Such individuals are known as Instagram celebrities of 'celebgrams'. Businesspeople see celebgrams as influential in terms of marketing potential. In recent years, endorsement services are very often used in promoting a product or service because it is considered an effective and efficient marketing method by companies. Therefore, many online businesses allocate large amounts of funds each year for endorsement activities using celebgram services (Wijaya \& Sugiharto, 2019).

Endorsements are usually carried out by celebrities or celebgrams ${ }^{1}$ (Damopolii, 2017). Companies use endorsement services as an advertising mode to increase consumer interest in products and/or services and someone who has made an endorsement will be financial compensated for it. From an economic point of view, the endorsement

\footnotetext{
${ }^{1}$ 'Celebrity' refers to artists, actors, musicians, and other art workers who are popular in a country. In contrast, 'celebgram' refers to individuals who have a lot of followers and significant influence on social media, usually Instagram, and who post significant creative content.
} 
clearly forms an additional income stream and this raises the potential for tax revenue. In Indonesia, the Directorate General of Taxes under the coordination of the Ministry of Finance is currently reviewing the tax system for the social-media sector. Improvements in tax systems and governance are crucial for optimizing the the government's tax collection efforts (Chen \& Tsai, 2018; Sebele-Mpofu, 2020).

Tax collection in Indonesia for individual income uses a self-assessment system in which taxpayers calculate and self-assess their tax obligations (Sofyani, Tahar, \& Murtin, 2019). This approach has the weakness of requiring taxpayers to be active in meeting their tax obligations, namely in calculating, reporting and paying. Situmorang (2019) contends that ignorance of the taxation system and its processes among celebrities makes collection of tax revenue from endorsement ineffective. Hasibuhan (2019) argues that in Indonesia the ineffectiveness of tax revenue collection from endorsement results from lack of clarity in the regulations and procedure for the taxing of such payments. This phenomenon is also experienced by many other countries, such as the difficulty in determining when online transactions should be taxed, and whether online transactions are tangible property, services or intangibles (Noronha \& Vinten, 2003). In addition, the lack of socialization related to the taxation of endorsement income has resulted in celebrities being less than compliant in their tax obligations (Palil, Akir, \& Ahmad, 2013).

Research related to taxes collected from endorsement income earned by celebgrams or from other activities on social media is still very scarce, especially in Indonesia. In fact, Indonesia's e-commerce market share is the largest in the ASEAN, reaching US\$40 billion in 2019 and recording four-fold growth since 2015 with an average growth rate of $49 \%$ per year (Ansah, 2019). These numbers show the potential for significant amounts of new state tax revenue from the e-commerce sector, including from endorsement activities. Hifani (2015) states that Singapore has designated influencers including celebrities as income tax objects. Damopolii (2017) argues that from a legal perspective, income earned by celebrities and YouTubers must be taxed in accordance with the provisions of legislation. In his research it is also stated that the government has an important role in disseminating laws and regulations. The government also needs to make reforms to the law in accordance with social and technological developments. From the study by Damopolii (2017) has risen a research gap related to how the tax treatment and mechanisms of endorsement income are operated technically from an accounting point of view, and this present research is conducted to address this gap. Explicitly, this research aims to answer the following problems:

1. How is the income of celebgrams derived from endorsement activities taxed?

2. What is the tax collection strategy for celebgram income from endorsement activities?

3. What are the celebgrams' perceptions around the application of endorsement tax?

This research is a pioneering study related to the topic of tax on social-media endorsement income. This study can therefore be seen as a prelude to more in-depth study in the future on a similar topic. From an economic viewpoint, this research is important in ensuring that the potential for state tax revenue can be maximized and the 
money generated from the revenue can be allocated for development. This study contributes to the literature in several ways. Theoretically, it adds to the body of knowledge by extending discussions of planned behaviour and attribution theory in endorsement tax compliance contexts. Practically, the implications of this research can be used as inputs for regulators seeking to optimize tax revenue from Indonesia's large e-commerce sector, and especially from endorsement activities.

\section{Literature Review}

This study employs two theoretical foundations, namely the theory of planned behaviour (TPB) (Ajzen, 1991) and the theory of attribution (Fritz, 1958). These two theories have been used to explore the perceptions (as a part of attitude) and intentions of celebgrams towards taxation of their endorsement activities.

\section{Theory of Planned Behavior}

Theory of planned behaviour (TPB) is an extension of the theory of reasoned action (TRA). In TRA, it is explained that a person's intention towards a particular behaviour is formed by two main factors, namely attitude towards the behaviour and subjective norms (Ajzen \& Fishbein, 1975), while in TPB one more factor is added, namely perceived behavioural control (Ajzen, 1991) (see Figure 1). As stated by Ajzen (1991), TPB is suitable for explaining any behaviour which requires planning, such as entrepreneurship. According to Ajzen (1991), attitude is a factor within a person (subject) who gives a positive or negative response to an assessment of something. The attitude towards behaviour is the degree to which a person exhibits a favourable or unfavourable evaluation of a behaviour. This depends on the person's assessment of the expected outcomes of that behaviour (Hardeman, Johnston, Johnston, Bonetti, Wareham, \& Kinmonth, 2002; Krueger \& Carsrud, 1993; Tung, 2011). For example, if someone thinks something is useful for them, they will give a positive response to it; on the contrary, if something is not useful then they will give a negative response. From this description, the tax obligations imposed on endorsement activities are very likely to foster a contingent attitude in a celebgram, either positive or negative.

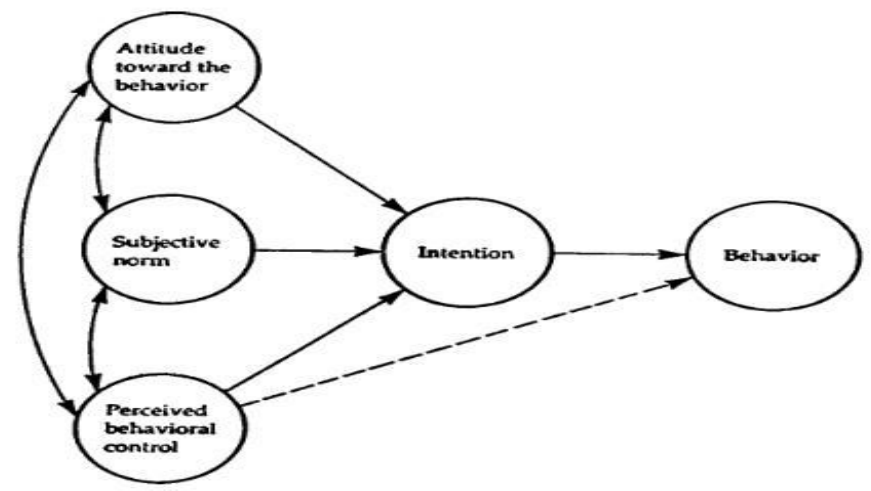

Figure 1 Theory of planned behaviour (TPB) Source (Ajzen, 1991, p. 182) 
A subjective norm is a person's perception of other people's thoughts that will support or not support them in doing something. A subjective norm is a social pressure faced by individuals to do or not do something (Ajzen, 1991). Tung (2011, p. 79) argues that '[a] subjective norm relates to the beliefs that other people encourage or discourage to carry out a behaviour'. An individual will tend to perform a behaviour if motivated by other people who also agree to do the behaviour (Hardeman et al., 2002; Malik \& Younus, 2019). This means that compliance with tax levied on endorsement activity would be related to public agreement. If the majority of celebgrams obey the endorsement tax, then it would trigger other celebgrams to obey too because they considered it as being the right thing to do.

Moreover, behavioural control is the perception of ease or difficulty in carrying out a behaviour (Ajzen, 1991). Behavioural control relates to beliefs about the availability of support and resources or the existence of barriers to performing an behaviour (control beliefs) (Tung, 2011; Malik \& Younus, 2019). This aspect is related to the ease or difficulty of implementing taxation. If tax processes make compliance difficult, then there is a high probability that celebgrams will be reluctant to fulfil their tax obligations, and vice versa.

\section{Theory of Attribution}

The theory of attribution was introduced by Heider (1958) and argues that humans are bound by psychological processes that connect their subjective experiences with various objects that exist. These various objects are then cognitively reconstructed in order to become sources of the consequences of perceptual experiences. Conversely, when people try to imagine an object, they will relate the experience to their 'realm'.

Furthermore, Heider (1958) argues that people tend to organize their attitudes so as not to cause conflict. For example, if a person agrees with someone's right to have an abortion, as do other people, then their attitude is consistent or balanced. However, if they agree with abortion but it turns out that their close friends and people around them do not agree with abortion, then they are in an imbalanced situation. As a result, they feel stressed, uncomfortable, and will try to change their attitude to adjust to the people around them, for example by acting as though they no longer completely agree with abortion. Through changing attitudes in this way, people become more comfortable. This condition indicates that in order to continue their activities and match with those around them, people interpret information to decide the causes of their and others behaviours. Moreover, Heider (1958) introduced the concept of 'causal attribution' - the process of explaining the causes of a behaviour. In everyday life, there are two types of causes, namely internal and external. Internal causes (internal causality) are attributes inherent in a person or their personal qualities, while external causes (external causality) exist in the environment or situation in which they are located.

In the context of this study, it can be assumed that attribution has an association with tax compliance. The absence of detailed regulations governing endorsement tax 
becomes the basis for one's cognition that complying with this tax may not be essential. This is closely related to what Heider (1958) previously explained: that the cause of a person's behaviour can be in the form of external causality, namely environmental and situational factors. Some studies using this theory in tax compliance contexts are highlighted in the next section.

\section{Proposition Development}

Studies related to taxation using TPB have been undertaken by some scholars. The focus of their studies is on whether the internal aspects of the individual, such as attitude and subjective norms, are related to tax awareness and eventually trigger tax compliance by an individual. Jimenez and lyer (2016) establish that societal norms and personal belief systems strengthen trust, and trust thus formed can strengthen the intention to comply with the tax system. Hastuti, Suryaningrum, Susilowati, Muchtolifah (2014) researched e-filing attitudes, subjective norms, and perceived behaviour control of taxpayers towards intention to use e-filing systems in Indonesia. They found that Indonesian citizens' intention to use e-filing facilities to report their annual tax income is dependent upon their attitudes and their behavioural controls on the system.

Andreas and Savitri (2015) discovered that taxpayers' awareness as determined by attitude and subjective norms has a full mediating role in the relationship between service quality and taxpayers' compliance. Moreover, a study undertaken by Bhutta, Rasheed, and Khan (2019) reveals that perceived behavioural control, subjective norms, attitude towards behaviour and moral obligation variables have noteworthy effects on the dependent variable (tax compliance behaviour). Intention to comply plays the role of mediator in the relationship between independent and dependent variables. However, the latest study undertaken by Sutrisno and Dularif (2020) reveals that subjective norms do not affect the tax compliance of taxpayers. These inconsistent results from previous research are an important basis for the need to further explore the TPB premise, especially in the context of endorsement taxes as a new issue in taxation.

Based on some prior studies mentioned above that use TPB as their theoretical underpinning, we formulate the following propositions as guidance for investigating celebgrams perceptions and intentions towards endorsement tax:

$\boldsymbol{P}_{1}$ : The celebgram's attitude will lead to the intention to comply with the endorsement tax.

$\boldsymbol{P}_{2}$ : Subjective norms believed by the celebgram will lead to the intention to comply with the endorsement tax.

$\boldsymbol{P}_{3}:$ Perceived behavioural control of the celebgram will lead to the intention to comply with the endorsement tax. 
Tahar, Rizkia, \& Hariyanto

Taxing Celebrity Social Media Endorsements Income: ...

Furthermore, using attribution theory, Paramaduhita and Mustikasari (2018) determined what factors may affect taxpayer compliance. They found that taxpayer's perceptions of penalties, law enforcement, tax treatment and the use of tax money simultaneously had positive effect on taxpayer's compliance. Pitaloka, Kardoyo, and Rusdarti (2018) found that tax socialization, as a part of external causality in attribution theory, increases understanding of tax regulations and has a significant effect on tax compliance. The same result was also obtained by Vousinas (2017). However, Yuniarta and Purnamawati (2020) found that external causality aspects of the individual such as tax socialization do not have a significant effect on tax compliance. The inconsistencies in the results of these prior studies suggest the importance of further exploration.

Starting from the premise put forward by Heider (1958) in attribution theory, and previous research results as highlighted above, we formulate another proposition as guidance for investigating the celebgram perception of tax regulation and its relationship with intentions around endorsement tax compliance:

$\boldsymbol{P}_{4}:$ Whether or not there are specific regulations as a situation (external) causality will affect the attitude of the celebgram in complying with the endorsement tax.

\section{Research Method}

This research adopts a qualitative approach and uses primary data. We use research by Sayidah and Assagaf (2019) as a reference in investigating tax issues using qualitative research designs. Qualitative research is descriptive in nature and tends to use analysis that focuses on process and meaning (a subject perspective) (Creswell \& Creswell, 2017; Patton, 1990). The data were gathered directly by conducting semi-structured interviews. This approach allowed the interviewers to have some control over the interview while giving the interviewees some space to present their views in more detail (Eriksson \& Kovalainen, 2008). This research was conducted in Yogyakarta, Indonesia. Determination of research informants used a purposive sampling approach aimed at finding data in accordance with predetermined criteria and the aims and objectives of the study (Sekaran \& Bougie, 2016; Zikmund, Babin, Carr, \& Griffin, 2013). The informants selected for this study are celebgrams domiciled in Yogyakarta who have more than 10,000 followers and often receive endorsement income, together with a tax official, tax consultant, tax academic, and information technology expert.

Before collecting research data through interviews, the researchers formally obtained permission from all informants by sending an official email and letter. After obtaining approval and arranging times and places to meet, the interviews were conducted faceto-face. Prior to the interviews, we also prepared an interview protocol and audio recording devices (Kvale \& Brinkmann, 2015). The interview protocol was used so that the interviews conducted did not deviate from the research objectives. This protocol was prepared not only based on research objectives but also based on theories relating to the problem under study. At the same time, the recording device was useful as a tool during interviews, enabling researchers to concentrate on the data collection process 
without having to stop to record answers from the informants. In data collection, audio interview recording was carried out after obtaining prior permission from all informants. The names of the informants were conveyed anonymously prior to the interview being conducted. This aimed to ensure informant confidence so that they would be willing to provide information and ideas in a flexible and unstressed manner (Cooper \& Schindler, 2014). We explained the objectives of this study and gave a free hand to informants to answer or not for every question asked.

Following Miles and Huberman (1992), the data analysis techniques adopted in this study were as follows: (1) data transcription, in which the conversion was converted into a written form. This was done on the same day as the interview so that all important information in a certain context was still remembered by the researcher for recording. The purpose of this process was to determine the adequacy of the data obtained so that it was relevant to the research focus; (2) data reduction, namely the process of selecting, separating, paying attention to simplification, abstracting and transforming raw data that arose from the written records created in the field. The amount of data obtained from the field was quite large, so it needed to be recorded carefully and in detail. Reducing data means summarizing, choosing the main mentions, and focusing on important mentions that match the problem formulation. Data reduction is a form of analysis that sharpens, classifies, directs, removes unnecessary information, and organizes data in such a way that final conclusions can be drawn and verified; (3) data display, which aimed to make it easier for researchers to see the overall picture or specific parts of the research. Data display was carried out through by describing the results of the interviews outlined in the form of description with narrative text, and supported by other important notes from when the interview was conducted to arrive at a conclusion; and (4) drawing of conclusions, as the conducting of continuous verification throughout the research process, namely during data collection. We tried to analyse and look for patterns, themes, similarities, things that often arose, hypotheses, and so on, and these are outlined in the conclusions. In this study, conclusions were drawn up by taking the essence of a series of categories of research results based on the results of the interviews.

To ensure the validity and reliability of the data, we conducted several procedures such as re-checking the results of transcriptions, to make sure no mistakes were made during the transcription process, and debriefing with fellow researchers (peer de-briefing) to improve the accuracy of research results (Creswell, 2012; Sofyani, Akbar, \& Ferrer, 2018).

\section{Result and Discussion}

To show the origin of the information gathered and to aid readability, the informants are codified as shown in Table 1. 
Tahar, Rizkia, \& Hariyanto

Taxing Celebrity Social Media Endorsements Income: ...

Table 1 Codification of informants

\begin{tabular}{|c|c|c|c|}
\hline No. & Code of informant & Job & Interview date \\
\hline 1 & TO & Tax official & 16 September 2019 \\
\hline 2 & Con & Tax consultant & 30 August 2019 \\
\hline 3 & Aca & Tax academic & 21 August 2019 \\
\hline 4 & IT & Information technology expert & 17 August 2019 \\
\hline 5 & Cel1 & Celebgram 1 & 31 July 2019 \\
\hline 6 & Cel2 & Celebgram 2 & 31 July 2019 \\
\hline 7 & Cel3 & Celebgram 3 & 4 August 2019 \\
\hline 8 & Cel4 & Celebgram 4 & 8 August 2019 \\
\hline 9 & Cel5 & Celebgram 5 & 14 August 2019 \\
\hline
\end{tabular}

Research Question (RQ) 1: What is the tax treatment of the income of celebgrams from endorsement activities?

\section{Tax Categorization of Endorsement Income}

From the interviews conducted with three of the informants - a tax official, a tax consultant, and a tax academic - it was found that income tax from endorsement activities can be treated in three ways: as main work income tax, as service activity income tax, and as income tax from side jobs which are recognized as wages or honoraria. Possible differences in the tax treatment of this endorsement income reflects differences in terms of calculation (tax base), withholding, and reporting, as well as the final or non-final nature of the tax. These three possible treatments are important for government consideration in determining tax regulations for income from endorsement activities.

"He/she (the celebgram) gets a fee from the advertisements they insert in their content, meaning that they seems to be selling services. Then what taxes will be imposed? The first is definitely income tax, and the second is value-added tax (VAT)" (\#TO).

"For a business, it (endorsement income) can also be subject to income tax no. 23 (for provision of services) of $0.5 \%$... if indeed it (endorsement income) meets the requirements, it is in that category" (\#TO).

“... it (treatment for income from endorsement) depends, there can be two (possible treatments), celebgram works personally or has management. If he/she is a person, he/she must report an annual tax return (ATR) every year. If the endorsement includes other (additional) income, the income must be added to the ATR. If he/she uses management, that means all income besides the endorsement is added up, for example, if he/she has other businesses" (\#Con)

Apart from being considered as eligible for income tax, we also found that endorsement activities can be subject to value-added tax (VAT). This is because endorsement is included in the category of selling/buying of services. However, what has not been specified is the endorsement VAT rate, whether $10 \%$, i.e. the same as the general VAT rate in Indonesia, or subject to a special rate such as, for example, freight forwarding, which is only $1 \%$. This lack of clarity is a strong argument for why it is urgent for the 
government to formulate specific rules related to endorsement taxation so that there is clarity for celebrities about when an income from endorsement activities can be taxed and what the payment and tax reporting procedures are.

RQ 2: What is the tax collection strategy for celebgram income from endorsement activities?

Before discussing the possibility of a strategy for taxing income from endorsement activities, we first present the obstacles government faces in optimizing the tax potential of such activities.

\section{Constraints Faced by Tax Officials}

From the interview conducted with the tax official, it is evident that the main obstacle faced by the Tax Directorate General in optimizing taxes from endorsement activities is related to the availability of complete information regarding the endorsement transactions carried out by celebgrams for companies/entrepreneurs. In addition, the very large number of celebgrams in Indonesia adds to the complexity of overseeing this tax.

“... The problem (endorsement tax by celebgrams) is related to data and information.... that is what we have not got so far..." (\#TO)

"With thousands of celebgrams, it is impossible for us to check one by one every day. The entrance is definitely from the data. The key is data. When the data is there, we can oversee their activities ..." (\#TO)

However, the limitations faced by the Tax Directorate General have not been followed up by the formation of a special unit to handle this celebgram tax. This can be seen clearly from the excerpt from an interview with the tax official who thinks that celebgram tax is the same as other income.

"Actually, it is the same as other taxpayers, there is no special treatment ..." (\#TO)

On the other hand, however, the tax official admits that the tax management technique applied must be different.

"This is something new to us regarding the problem, not the regulation, but the business process... what is the tax treatment now? Yes, still using the old one (regulation), there is no difference." (\#TO)

The next obstacle we found was that the realization of potential taxes among celebgrams still depends on the employer/organization. This means that if the employer deducts the celebgram's tax on the amount paid for endorsement services, that tax will be received by the government, while if the employer does not make the deduction, the potential tax will not be realized. 


\footnotetext{
"As long as the seller issues a tax invoice, we will know what kind of transaction it is, and we can trace it then..." (\#TO)
}

Furthermore, according to a tax academic, the problem faced by the Tax Directorate General regarding the optimization of tax take from celebgrams is that there is no truly capable person in the Tax Directorate General who fully understands the celebgram business model or the appropriate method to supervise its taxation.

“... There are no capable people at the tax office regarding the collection of endorsement and celebgram taxes. The way to overcome the obstacles is to find people who master the system and who master the model of how celebrities operate..." (\#Aca)

\section{The Strategy for Endorsement Tax Collection}

From the interview results, it was found that thus far the Tax Directorate General has relied on third parties for deducting income tax from the endorsement activities of celebgrams. As a result, when the employer does not make a deduction, the celebgrams do not pay the tax. The tax official claims that because of the self-assessment nature of individual tax, celebgrams are required to actively manage their tax obligations on the basis of their own awareness of the legal requirements. However, hoping that celebgrams are aware of their tax obligations when they actually do not understand them will lead to sub-optimal tax collection. For this reason, a possible strategy other than relying on third-party employers is to ask for help from other third parties such as banks to track the expenditure transactions of celebgrams. From this information, it will be evident how much celebgrams' monthly expenses are, and from this can be deduced how much wealth they have. Also, this can be the entry point for auditing celebgrams receiving high-value endorsements.

Another possibility is the formation of a special unit so that tax control in the socialmedia sector can be run effectively. The taxation academic surveyed claims that to optimize the exploration of tax potential from endorsement activities a special unit needs to be created so that endorsement tax management can be run effectively and efficiently. A special team that is capable in the field of information technology is needed, given that endorsement occurs in the world of social media. The tax consultant interviewee suggested that tax takes from endorsement activities must involve a third party, namely employers or banks and the social-media developers where endorsement activities occur.

"... we have to control, have cooperation from third parties or parties that provide jobs to them." (\#Con)

The tax payments made by the employer can be used as a technical strategy for the taxation of celebgrams. The government could apply a policy in which, if the employer does not withhold tax on the endorsement income of celebgrams as instructed, the tax is imposed on the employer themselves. Thus, the employer as a third party will be encouraged to deduct the endorsement tax. For this purpose, experts in IT, social media and digital business processes are needed to collect data and monitor celebgram 
accounts, especially as related to their activities on social media. Account blocking mechanisms can be implemented if celebgrams are identified as violating tax regulations.

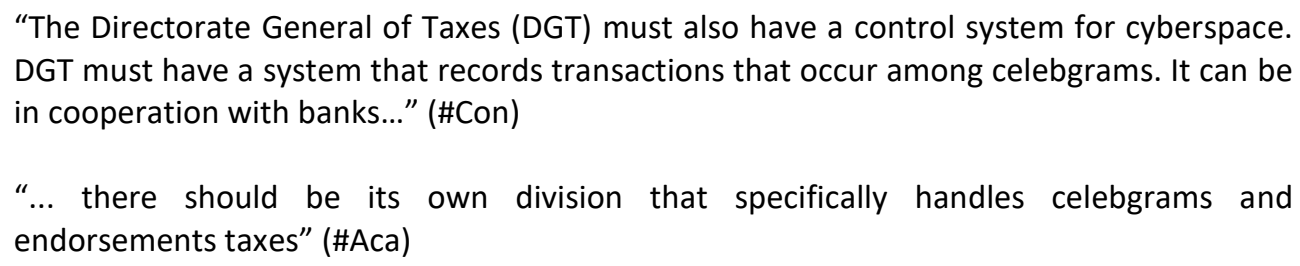

RQ 3: What are celebgrams' perceptions about the application of endorsement tax?

\section{Celebgrams' Tax Knowledge}

From the interviews conducted, it was found that none of the celebgrams carried out their tax obligations. This is confirmed by evidence in which they admit that they do not have Taxpayer Identification Numbers (TINs). All celebgram informants said that they had never received specific tax socialization information from the government through their Instagram account inboxes and stated that this is the reason they do not fulfil their tax obligations. So far, their knowledge regarding taxation has been obtained from mass media and lectures. Meanwhile, the tax official informant claims that the directorate has a tax socialization team for income seekers in cyberspace, including celebgrams. These findings indicate that the efforts of the Tax Directorate General in disseminating taxation information to celebgrams is still not optimal. This is an important consideration for the government.

"... we do tax socialization to celebgrams through social media by sending messages to their accounts .... we have a community and we usually do socialization ..." (\#TO)

"In particular, I never got socialization from the Director General of Taxes ... so I learned tax from Instagram because I followed the finance minister." (\#Cel2)

“... I have not received tax socialization yet. I studied tax on campus ..." (\#Cel3)

“... no (socialization related to taxes). But I know a little about taxes from social media, namely Instagram and Twitter ..." (\#Cel4)

\section{Celebgrams' Perception of Endorsement Tax}

From the interview results, we found that three out of five celebgrams agreed that their income from endorsement activities should be taxed as long as there were certain limits. From our interpretation, the limits here refer to clear rules regarding how much income is subject to tax and how to report income and process payments. This is intended to ensure that there is no confusion among celebgrams, the majority of whom, in fact, do not understand their tax obligations in relation to the income they earn from endorsement activities. 
Tahar, Rizkia, \& Hariyanto

Taxing Celebrity Social Media Endorsements Income: ...

"It is okay if it (endorsement income) is taxed ... the important thing is it is still reasonable, right? We have received income from there (Instagram) ... just agree if you (government) want to apply as long as there are limits" (\#Cel1)

"Yes, agree, because that is indeed an income ..." (\#Cel2)

However, we also found that two celebgrams considered that their income from endorsement activities should not be taxed. They argued that the endorsement income for their business was obtained by their own efforts without any contribution from the government. Hence, when the income they receive has to be taxed, they consider it unfair. In addition, the lack of clarity of endorsement tax regulation was also the reason for Cel5 not to be willing to take care of their tax obligations.

"For me, I do not agree ... we are doing our own business, and there is no connection with the government. So, in my opinion, there is no need for our income from the endorsement to be deducted for tax" (\#Cel4).

"I do not agree, because, in my opinion, the endorsement tax is unclear in terms of how much the inclusion is. So, we do not know how much tax should be paid ..." (\#Cel5)

From the arguments of these two celebgrams, it is important that the government in particular should note the importance not only of exploring tax potential but also of providing benefits to celebgrams as taxpayers, albeit indirectly. This aims to show to the public that the government does not appear to want to profit from its efforts without providing benefits to the community. In addition, simplifying the process of taxation would increase tax compliance among celebgrams.

Based on our investigations, it is found that endorsement income can be subject to three types of income tax: regular, additional, and service provision. In addition, this income is also a possible subject for VAT. These possibilities are important for consideration by the Tax Directorate General in determining specific regulations related to endorsement taxation. At present, however, the absence of specific taxation regulations on endorsement income makes it unclear how it should be treated. Andreas and Savitri (2015) argues that a clear understanding of tax regulations by taxpayers and the quality of service that taxpayers receive have an influence on taxpayer compliance. Hasseldine, Hite, James, and Toumi (2007) also found that persuasive communication from tax units will provide clarity to taxpayers regarding their tax obligations. This policy will contribute to improving tax compliance by taxpayers. Hence, specific regulation and a special unit controlling all matters relating to taxes on social-media activities is pivotal. These suggestions are in line with the premises of TPB (Ajzen, 1991), in that the presence of specific and legitimate regulations will become preferences that shape the subjective norms of celebgrams and subsequently will relate to their attitudes and behavioural intentions. In addition, from the attribution theory point of view, the existence of regulation becomes an external causality that will become a consideration in celebgrams' cognitions around their behaviour (Heider, 1958). This is because formal regulations on endorsement taxes would shape the public's perception such that if someone violates the regulation, then that person is judged as being 'bad'. Thus, specific 
regulation will lead to the encouragement of celebgrams to comply with endorsement tax to avoid stigmatization and to present balanced behaviour to society.

Furthermore, this study also confirms that the celebgrams interviewed had not fulfilled their tax obligations because they had never received socialization by the Tax Directorate General regarding their tax obligations. However, the Directorate General claims that they are disseminating taxation information to celebgrams through social media. This indicates that the socialization delivered online to businesses, and especially to celebgrams, is still not optimal. This finding is an important point for the government as the tax regulator. Based on this finding it can be interpreted that the poor effectiveness of socialization has led to insufficient understanding among celebgrams of their tax obligations, which in turn leads to non-compliance with tax obligations. However, it was in fact found that the celebgrams had the intention to comply with taxation regulations. This can be seen from the approval of the majority of the celebgrams of the idea of endorsement income tax if properly regulated. Additionally, we found that the celebgrams who had the intention to comply were those with little knowledge of taxation. Therefore, it is crucial for the government to intensify and improve the effectiveness of its endorsement tax outreach programme to celebgrams.

Savitri and Musfialdy (2016) found that the tax socialization carried out by the government is an important factor in increasing individual taxpayer compliance. Meanwhile, Pitaloka et al. (2018) found that the socialization of taxation affects and strengthens the relationship between understanding tax rules and taxpayer compliance. Moreover, this finding confirms the premise of TPB that knowledge owned by a person can lead to awareness of an obligation and is associated with attitudes and subjective norms. This will lead to an intention to behave obediently (Andreas \& Savitri, 2015; Bhutta et al., 2019). This finding also confirms attribution theory, in that socialization as an external causality that will encourage individuals to behave obediently, in this case in the aspect of taxation (Heider, 1958). This is because people who are the objects of socialization will experience increased knowledge and awareness regarding the obligations they must fulfil.

In addition, it was found that the majority of the celebgrams (three out of five) agreed with the imposition of tax on their income from endorsement activities. They felt that the imposition of tax would be acceptable as long as the taxation process was fair, simple and clearly regulated. In terms of fairness, they expected that only income above the non-taxable income threshold of Rp4,500,000 (equivalent at around US\$322) should be taxed in the current Indonesian context. This is in line with findings by Siahaan (2012), Mukhlis, Utomo, and Soesetio (2015), Azmi, Zainuddin, Mustapha, and Nawi (2016), and Alshira'h and Abdul-Jabbar (2019) that in order to improve tax compliance, the aspect of justice provided by the government to the community has a very crucial role. Meanwhile, to increase the perception of taxpayer fairness, effective two-way communication between tax authorities and taxpayers is significant (Azmi et al., 2016; Siahaan, 2012). Additionally, this finding is consistent with Musimenta (2020) who suggests that easy taxation processes will encourage tax compliance. Therefore, the complexity of tax administration that often occurs in developing countries must be 
addressed. Tambun and Kopong (2017) found that the existence of e-filing technology has a significant effect on the willingness of taxpayers to fulfil their tax obligations. The same results were also found by several studies (e.g. Indah \& Setiawan, 2020; Obert, Rodgers, Tendai, \& Desderio, 2018; Purba, Simanjuntak, Rumapea, Sembiring, Siahaan, Goh, \& Purba, 2019; Solichah \& Soewarno, 2019). In addition to improving the ease of handling taxes, e-tax applications will also make it easier to trace the track record of the tax obligations of celebgrams (Sofyani, Riyadh, \& Fahlevi, 2020; Maulana Yusup, Hardiyana, \& Sidharta, 2015).

From the TPB point of view, an easier tax system will be related to the perceived behavioural control of celebgrams (Ajzen, 1991). Perceived behavioural control is related to the perception of whether endorsement tax processing is easy or difficult or even personally detrimental (Malik \& Younus, 2019). Musimenta (2020) discovered that if taxpayers find it easy to settle tax obligations, then there would be an intention to comply with them, and similar research results have been obtained by Hastuti et al., (2014), Jimenez and lyer (2016) and Bhutta et al. (2019). In addition, this finding also relates to attribution theory in which Heider (1958) explains that the environment, in this case the tax system (Musimenta, 2020; Paramaduhita \& Mustikasari, 2018), will affect tax compliance.

Another issue is that two of the interviewed celebgrams disagree that their income from endorsement should be taxed. The absence of any government contribution in providing endorsement work and unclear endorsement tax regulations are their reasons for this view. This finding is important for the Tax Directorate General to consider, so that efforts can be made to optimize income tax from endorsement income not only by emphasizing the legitimacy of activity by the government in 'asking for money' from people but also by providing benefits to celebgrams as taxpayers, albeit indirectly. In addition, it is again important to note that unclear regulatory issues made celebgrams reluctant to process their tax payments. Unfortunately, the tax authorities claim that because Indonesia adheres to a self-assessment system, individual taxation is an obligation of each person. Tax officials indirectly give the impression that there is no assistance from the government regarding tax management, and that every income earner must take care of their own tax obligations.

However, as well as the self-assessment system which obliges individuals to take care of taxes independently, the government through the Tax Directorate General should actively participate in providing facilities that make taxation easier, for example by providing special e-tax applications for calculation, reporting and payment, as already highlighted above. The convenience provided will create an image of the government's contribution to assisting celebgrams in fulfilling their tax obligations. This will make it easier for celebgram taxpayers, and thus it is hoped that they will be more willing to fulfil their tax obligations (Musimenta, 2020). 
Tahar, Rizkia, \& Hariyanto

Taxing Celebrity Social Media Endorsements Income: ...

\section{Conclusion}

This study aims to investigate how the income tax treatment of income from endorsement activities is operated in Indonesia, what the tax withholding strategy is for endorsement tax, and the perceptions of celebgrams about the application of tax to their endorsement income. This study concludes that the income tax on endorsement activities could be taxed in the category of general income tax and value-added tax. This research also discovers that not all celebgrams fulfil their tax obligations. This is due to a lack of understanding of taxes among celebgrams and to their not receiving adequate socialization related to taxation from the Tax Directorate General. However, it was found that the majority of celebgrams agreed that their income from endorsement should be taxed as long as the treatment was fair and there was clear regulation.

Another finding is that the treatment of income tax from endorsement activities by celebgrams is still not specifically regulated. The lack of effective tax socialization or the provision of services to celebgrams by the Tax Directorate General is also a crucial point. These issues make some celebgrams reluctant to pay their taxes. Moreover, data and information problems due to the absence of a special unit handling taxes from the ecommerce sector and a lack of employees who are capable in the field of e-commercebased business processes are also obstacles in optimizing the exploration of tax potential among celebgrams in particular.

Arising from these findings, the strategies that need to be considered by the government to optimize the realization of tax potential in the e-commerce sector, especially from the endorsement income of celebgrams, are as follows: first, there is a need for specific regulations that regulate the technical treatment of endorsement tax calculations, reporting and payment. Second, socialization related to taxation obligations needs to be reconsidered, given that what has been done so far has not been effective. It is important to consider the implementation of e-tax systems to make it easier for celebgrams to handle their taxes and thus to increase their tax compliance. Third, and crucially, it is necessary for the government to consider the formation of a special unit under the Tax Directorate General to handle taxes from the e-commerce sector. Recruitment of millennial employees who are capable in the field of ecommerce-based business processes and who have the required knowledge related to information-technology-based control mechanisms, auditing and accounting is also highly recommended.

\section{Acknowledgement}

The researchers would like to extend his gratitude to the Universitas Muhammadiyah Yogyakarta. This research is funded under Penelitian Dasar Kolaboratif Dalam Negeri 2019/2020 scheme. Letter of Assignment Number: 034/PEN-LP3M/1/2020. 


\section{References}

Ajzen, I. (1991). The theory of planned behavior. Organizational Behavior and Human Decision Processes, 50(2), 179-211. https://doi.org/10.1016/0749-5978(91)90020-T

Ajzen, I., \& Fishbein, M. (1975). A Bayesian analysis of attribution processes. Psychological bulletin, 82(2), 261-277. https://doi.org/10.1037/h0076477

Alshira'h, A. F., \& Abdul-Jabbar, H. (2019). The effect of tax fairness on sales tax compliance among Jordanian manufacturing SMEs. Academy of Accounting and Financial Studies Journal, 23(2), 1-11. Retrieved from https://www.abacademies.org/articles/theeffect-of-tax-fairness-on-sales-tax-compliance-among-jordanian-manufacturing-smes8091.html

Andreas, \& Savitri, E. (2015). The effect of tax socialization, tax knowledge, expediency of tax ID number and service quality on taxpayers compliance with taxpayers awareness as mediating variables. Procedia-Social and Behavioral Sciences, 211, 163-169. https://doi.org/10.1016/j.sbspro.2015.11.024

Ansah, S. (2019). Pangsa Pasar E-Commerce Indonesia Tembus USD40 Miliar (Indonesia's E-Commerce Market Share Reaches USD40 Billion). Retrieved from https://www.makassarinside.com/pangsa-pasar-e-commerce-indonesia-tembususd40miliar/\#: :text=Makassarinside.com $\% 2 \mathrm{C} \% 20$ Jakarta $\% 20 \% \mathrm{E} 2 \% 80 \% 93 \% 20 \mathrm{Pangsa}$,ra ta $\% 2$ Drata $\% 2049 \% 25 \% 20$ setahun

Azmi, A. A. C., Zainuddin, S., Mustapha, M. Z., \& Nawi, Y. (2016). The Mediating Effect of Tax Fairness on the Relationship Between Knowledge, Complexity and Voluntary Tax Compliance. Asian Journal of Accounting Perspectives, 9(1), 1-12. https://ajap.um.edu.my/article/download/5897/3613/

Bhutta, Z. M., Rasheed, R., \& Khan, A. B. (2019). Psychological Factors Affecting Tax Compliance Behavior of Pakistani Tax Payer: An Extended Theory of Planned Behavior Perspective. Pakistan Journal of Social Sciences (PJSS), 39(4), 1453-1464. Retrieved from http://piss.bzu.edu.pk/website/journal/article/5ed2b115245dc/page

Cahyono, A. S. (2016). The influence of social media on social change in Indonesia. Jurnal Publiciana, 9(1), 140-157. Retrieved from http://jurnalunita.org/index.php/publiciana/article/view/79

Chen, K.-S., \& Tsai, H. (2018). Taxing the rich policy, evasion behavior, and portfolio choice: A sustainability perspective. Cogent Business \& Management, 5(1), 1-20. https://doi.org/10.1080/23311975.2018.1526362

Cooper, D., \& Schindler, P. (2014). Business Research Methods. The McGraw- Hill Companies.

Creswell, J. W. (2012). Research Design: Qualitative, Quantitative and Mixed Methods Approaches. California: Sage Publication.

Creswell, J. W., \& Creswell, J. D. (2017). Research design: Qualitative, quantitative, and mixed methods approaches. California: Sage publications.

Damopolii, I. N. (2017). Pajak Penghasilan Pada Kegiatan Youtuber Dan Selebgram Dalam Penggunaan Media Sosial Berdasarkan Undang Undang Nomor 36 Tahun 2008 Tentang Pajak Penghasilan. Lex Privatum, 5(3), 67-72. Retrieved from https://ejournal.unsrat.ac.id/index.php/lexprivatum/article/view/15870

Eriksson, P., \& Kovalainen, A. (2008). Qualitative research in business studies. London: Sage Publication.

Febiyan, A. (2015). Pengertian Instagram dan Keistimewaanya (Understanding Instagram and Its Features). Retrieved from https://www.dumetdevelopment.com/blog/pengertian-instagram-dankeistimewaannya 
Tahar, Rizkia, \& Hariyanto

Taxing Celebrity Social Media Endorsements Income: ...

Fritz, H. (1958). The psychology of interpersonal relations. New York: John Wiley.

Hardeman, W., Johnston, M., Johnston, D., Bonetti, D., Wareham, N., \& Kinmonth, A. L. (2002). Application of the theory of planned behaviour in behaviour change interventions: A systematic review. Psychology and Health, 17(2), 123-158. https://doi.org/10.1080/08870440290013644a

Hasibuhan, L. S. (2019). Curahan Hati Youtuber yang Masih Kebingungan Soal Pajak (Youtubers Still Confused about the Tax). Retrieved from https://www.cnbcindonesia.com/news/20190113122455-4-50410/curahan-hatiyoutuber-yang-masih-kebingungan-soal-pajak

Hasseldine, J., Hite, P., James, S., \& Toumi, M. (2007). Persuasive communications: Tax compliance enforcement strategies for sole proprietors. Contemporary Accounting Research, 24(1), 171-194. https://doi.org/10.1506/P207-004L-4205-7NX0

Hastuti, S., Suryaningrum, D. H., Susilowati, L., \& Muchtolifah. (2014). Implementation of Decomposed Theory of Planned Behavior on the Adoption of E-Filling Systems Taxation Policy in Indonesia. Expert Journal of Business and Management, 2(1), 1-8. Retrieved from http://business.expertjournals.com/ark:/16759/EJBM 201hastuti2014pp1-8.pdf

Hifani, N. (2015). Terpisah dari Kementerian Keuangan, IRAS Lebih Leluasa. Retrieved from https://www.majalahpajak.net/terpisah-dari-kementerian-keuangan-iras-lebihleluasa/

Indah, N. P. I. P., \& Setiawan, P. E. (2020). The Effect of Tax Awareness, Taxation Sanctions, and Application of E-Filing Systems In Compliance With Personal Taxpayer Obligations. American Journal of Humanities and Social Sciences Research, 4(3), 440-446. Retrieved from https://www.ajhssr.com/the-effect-of-tax-awarenesstaxation-sanctions-and-application-of-e-filing-systems-in-compliance-with-personaltaxpayer-obligations-2/

Jimenez, P., \& Iyer, G. S. (2016). Tax compliance in a social setting: The influence of social norms, trust in government, and perceived fairness on taxpayer compliance. Advances in Accounting, 34, 17-26. https://doi.org/10.1016/j.adiac.2016.07.001

Keegan, B. J., \& Rowley, J. (2017). Evaluation and decision making in social media marketing. Management Decision, 55(1), 15-31. https://doi.org/10.1108/MD-10-2015$\underline{0450}$

Krueger, N. F., \& Carsrud, A. L. (1993). Entrepreneurial intentions: Applying the theory of planned behaviour. Entrepreneurship \& Regional Development, 5(4), 315-330. https://doi.org/10.1080/08985629300000020

Kvale, S., \& Brinkmann, S. (2015) Interviews: Learning the Craft of Qualitative Research Interviening. 3rd Edition. Sage Publications, Thousand Oaks, CA.

Malik, M. S., \& Younus, S. (2019). Determinants of Tax-Compliance Behaviour Explored by Slippery Slope Framework and Theory of Planned Behaviour: An Evidence from Small Business Owner. Journal of Management Sciences, 6(2), 33-47. https://doi.org/10.20547/ims.2014.1906203

Miles, M. B., \& Huberman, A. M. (1992). Qualitative data analysis. USA: Sage Publication.

Mukhlis, I., Utomo, S. H., \& Soesetio, Y. (2015). The role of taxation education on taxation knowledge and its effect on tax fairness as well as tax compliance on handicraft SMEs sectors in Indonesia. International Journal of Financial Research, 6(4), 161-169. https://doi.org/10.5430/ijfr.v6n4p161

Musimenta, D. (2020). Knowledge requirements, tax complexity, compliance costs and tax compliance in Uganda. Cogent Business \& Management, 7(1), 1-20. https://doi.org/10.1080/23311975.2020.1812220 
Noronha, C., \& Vinten, G. (2003). Taxation of ecommerce in Hong Kong: applying UK and US experience. Managerial Auditing Journal, 18(9), 702-709. https://doi.org/10.1108/02686900310500451

Obert, S., Rodgers, K., Tendai, M. J., \& Desderio, C. (2018). Effect of e-tax filing on tax compliance: A case of clients in Harare, Zimbabwe. African Journal of Business Management, 12(11), 338-342. https://doi.org/10.5897/AJBM2018.8515

OkeFinance. (2019). Membedah Gelimang Penghasilan Selebgram Indonesia. Retrieved from https://www.economy.okezone.com/read/2019/02/14/320/2017981/membedahgelimang-penghasilan-selebgram-indonesia

Palil, M. R., Akir, M., \& Ahmad, W. (2013). The perception of tax payers on tax knowledge and tax education with level of tax compliance: a study the influences of religiosity. ASEAN Journal of Economics. Management and Accounting, 1(1), 118-129. Retrieved from http://fem.ipb.ac.id/miicema/e-journal/v1n1/8.pdf

Paramaduhita, A. V., \& Mustikasari, E. (2018). Non-employee individual taxpayer compliance. Asian Journal of Accounting Research, 3(1), 112-122. https://doi.org/10.1108/AJAR-06-2018-0007

Patton, M. Q. (1990). Qualitative evaluation and research methods: Sage Publications.

Pitaloka, L. K., Kardoyo, K., \& Rusdarti, R. (2018). The socialization of tax as a moderation variable towards the taxpayer compliance of industrial performer in kudus regency. Journal of Economic Education, 7(1), 45-51. Retrieved from https://journal.unnes.ac.id/sju/index.php/jeec/article/view/24059

Purba, D. H. P., Simanjuntak, M., Rumapea, M., Sembiring, Y. N., Siahaan, S. B., Goh, T. S., \& Purba, E. N. (2019). The Effect of Implementation of E-Filing System on Taxpayer Compliance with the Understanding of the Internet. Paperpresented at the 2019 International Conference of Computer Science and Information Technology (ICoSNIKOM). Retrieved from https://ieeexplore.ieee.org/xpl/conhome/9107303/proceeding

Rahman, I. A., \& Panuju, R. (2017). Communication Strategy for Fair N Pink Product Marketing through Instagram Social Media. WACANA: Jumal Ilmiah Ilmu Komunikasi, 16(2), 214-224. https://doi.org/10.32509/wacana.v16i2.26

Savitri, E., \& Musfialdy. (2016). The effect of taxpayer awareness, tax socialization, tax penalties, compliance cost at taxpayer compliance with service quality as mediating variable. Procedia-Social and Behavioral Sciences, 219, 682-687. https://doi.org/10.1016/i.sbspro.2016.05.051

Sayidah, N., \& Assagaf, A. (2019). Tax amnesty from the perspective of tax official. Cogent Business \& Management, 6(1), 1-20. https://doi.org/10.1080/23311975.2019.1659909

Sebele-Mpofu, F. Y. (2020). Governance quality and tax morale and compliance in Zimbabwe's informal sector. Cogent Business \& Management, 7(1), 1-20. https://doi.org/10.1080/23311975.2020.1794662

Sekaran, U., \& Bougie, R. (2016). Research methods for business: A skill building approach. New Jersey: John Wiley \& Sons.

Siahaan, F. O. (2012). The influence of tax fairness and communication on voluntary compliance: trust as an intervening variable. International Journal of Business and Social Science, 3(21), 191-198. Retrieved from http://www.ijbssnet.com/journals/Vol 3 No_21_November_2012/20.pdf

Situmorang, A. (2019). Ini Alasan Youtuber dan Selebgram Mangkir Bayar Pajak (This is the reason why YouTuber and Celebrity are absent from paying taxes). Retrieved from https://www.merdeka.com/uang/ini-alasan-youtuber-dan-selebgram-mangkir-bayarpajak.html

Sofyani, H., Akbar, R., \& Ferrer, R. C. (2018). 20 Years of Performance Measurement System (PMS) Implementation in Indonesian Local Governments: Why is Their 
Performance Still Poor?. Asian Journal of Business and Accounting, 11(1), 151-227. https://doi.org/10.22452/ajba.vol11no1.6

Sofyani, H., Riyadh, H. A., \& Fahlevi, H. (2020). Improving service quality, accountability and transparency of local government: The intervening role of information technology governance. Cogent Business \& Management, 7(1), 1-20. https://doi.org/10.1080/23311975.2020.1735690

Sofyani, H., Tahar, A., \& Murtin, A. (2019). Perpajakan di Indonesia (Taxation in Indonesia). Yogyakarta: Baskara Media.

Solichah, N. N., \& Soewarno, N. (2019). The Effect of E-Filing Implementation, Level of Tax Comprehension, and Tax Sanction on Formal Compliance of Individual Taxpayer. Paper presented at the 2018 International Conference on Islamic Economics and Business (ICONIES 2018). Retrieved from https://www.atlantispress.com/proceedings/iconies-18

Sutrisno, T., \& Dularif, M. (2020). National culture as a moderator between social norms, religiosity, and tax evasion: Meta-analysis study. Cogent Business \& Management, 7(1), 1 18. https://doi.org/10.1080/23311975.2020.1772618

Tambun, S., \& Kopong, Y. (2017). The Effect of E-Filing on The of Compliance Individual Taxpayer Moderated By Taxation Socialization. South East Asia Journal of Contemporary Business, Economics and Law, 13(1), 45-51. Retrieved from http://www.seajbel.com/wpcontent/uploads/2017/11/ACC-267.pdf

Tung, L. C. (2011). The impact of entrepreneurship education on entrepreneurial intention of engineering students. City University of Hongkong: Run Run Shaw Library, 11(1), 67-86. Retrieved https://scholars.cityu.edu.hk/en/theses/theses(5b5fccf9-280b-4df0-a3c261ea70ea35ea).html

Utami, M. A., Lestari, M. T., \& Putri, B. P. S. (2016). Analysis of Marketing Communication Strategy of Telkom University in 2015/2016 through social media Instagram. eProceedings of Management, 3(1), 859-866. Retrieved from https://core.ac.uk/download/pdf/299906057.pdf

Virtanen, H., Björk, P., \& Sjöström, E. (2017). Follow for follow: marketing of a start-up company on Instagram. Journal of Small Business and Enterprise Development, 24(3), 468484. https://doi.org/10.1108/JSBED-12-2016-0202

Vousinas, G. L. (2017). Shadow economy and tax evasion. The Achilles heel of Greek economy. Determinants, effects and policy proposals. Journal of Money Laundering Control, 20(4), 386-404. https://doi.org/10.1108/jmlc-11-2016-0047

Wijaya, F., \& Sugiharto, S. (2015). Pengaruh Celebrity Endorsement Terhadap Purchase Intention Denganbrand Image Sebagai Variabel Intervening (Studi Kasus Iklan Produk Perawatan Kecantikan Pond's). Jurnal Manajemen Pemasaran, 9(1), 16-22. https://doi.org/10.9744/pemasaran.9.1.16-22

Yuniarta, G. A., \& Purnamawati, I. G. A. (2020). Spiritual, psychological and social dimensions of taxpayers compliance. Journal of Financial Crime, 27(3), 1-13. https://doi.org/10.1108/ifc-03-2020-0045

Yusup, M., Hardiyana, A., \& Sidharta, I. (2015). User acceptance model on e-billing adoption: A study of tax payment by government agencies. Asia Pacific Journal of Multidisciplinary Research, 3(4), 150-157. Retrieved from http://www.apjmr.com/wpcontent/uploads/2015/11/APJMR-2015-3.4.5.19.pdf

Yusup, M., Rais, N. S. R., \& Sari, Y. K. (2018). Representasi Pemasaran Melalui Majalah Mini Menggunakan Media Sosial Instagram. Journal Cerita, 4(1), 63-75. https://doi.org/https://doi.org/10.33050/cerita.v4i1.629

Zikmund, W. G., Babin, B. J., Carr, J. C., \& Griffin, M. (2013). Business research methods. Boston: Cengage Learning. 